\title{
Nature and Specificity of the Immune Response to Collagen in Type II Collagen-induced Arthritis in Mice
}

\author{
John M. Stuart, Alexander S. Townes, and Andrew H. Kang, Veterans \\ Administration Medical Center and the University of Tennessee Center for \\ the Health Sciences, Memphis, Tennessee 38104
}

A в S T R A C T To determine the role of collagen-immunity in the development of collagen-induced arthritis, DBA/l mice were immunized with type II collagen and observed for the development of polyarthritis. $96 \%$ of the mice immunized with native type II collagen developed inflammatory arthritis between 4 and 5 wk after primary immunization. Immunization with denatured type II collagen in exactly the same manner was not effective in inducing arthritis. Cell-mediated immunity in arthritic mice was assessed by measuring $\left[{ }^{3} \mathrm{H}\right]$ thymidine incorporation by mononuclear cells cultured in the presence of collagen. The maximal proliferative response to collagen occurred at 2 wk after immunization. Equally good incorporation of label occurred when cells were cultured with native or denatured type II collagen or type I collagen. The cellular response of nonarthritic mice immunized with denatured collagen was indistinguishable from that seen in arthritic mice. Humoral immunity was assessed by an ELISA assay for antibodies to collagen. The immunoglobulin $M$ (IgM) response peaked at $2 \mathrm{wk}$ and the IgG response at $5 \mathrm{wk}$ after immunization. Antisera from arthritic mice immunized with native type II collagen were relatively specific for conformational determinants on the native type II molecule although some reactivity with denatured collagen was noted. Antisera from nonarthritic mice immunized with denatured collagen primarily recognized covalent structural determinants. It was concluded that native type II collagen was essential for the induction of arthritis and that an antibody response specific for native type II collagen may be important for the development of arthritis.

\section{INTRODUCTION}

There has been renewed interest in collagen autoimmunity as a cause of arthritis since the discovery that

\footnotetext{
Received for publication 17 June 1981 and in revised form 16 November 1981.

Address reprint requests to Dr. Townes.
}

immunization of rats with native type II collagen results in an inflammatory polyarthritis (1). This arthritis is associated with high levels of both cell-mediated and humoral immunity to collagen and it is believed that collagen immunity is responsible for the development of arthritis $(2,3)$. Although the immune response in rats has been studied in some detail, the pathogenesis of the arthritis remains incompletely understood. In fact some authors have emphasized cell-mediated immune mechanisms in its etiology (4) whereas others have emphasized humoral mechanisms (3). Collagen immunity has also been described in association with human rheumatoid arthritis (5-8), relapsing polychrondritis (9), and other rheumatic diseases $(8,10$, 11) although its role in their pathogenesis is unknown.

It has recently been reported that mice immunized with bovine type II collagen will develop an arthritis similar to that seen in rats (12). However, there were some differences between the development of arthritis in mice as compared with rats. In particular, mice developed disease after a longer latent interval and after a booster immunization. No studies of collagen immunity in these arthritic mice have been reported. We undertook a detailed study of the time-course and specificity of the immune reaction of mice that develop arthritis in response to type II collagen in order to determine the relationship of collagen immunity to the development of arthritis.

\section{METHODS}

Mice. DBA/1J mice were obtained from The Jackson Laboratory, Bar Harbor, Maine. Only male mice between 8 and 12 wk of age were used. They were maintained on absorbent bedding (Bed O'Cobs, The Andersons, Cob Division, Maumee, Ohio) in plastic cages and fed standard Purina rodent chow (Ralston Purina Co., St. Louis, Mo.).

Preparation of collagen. Most experiments used native type II collagen prepared by limited pepsin digestion of pulverized chick sternal cartilage and purified as described (13). For studies of cross-reactivity type I collagen was isolated and purified from lathyritic chick skin, and bovine type II collagen was isolated and purified from fetal calf 
articular cartilage. The details of the methods used to prepare these collagens have been published $(14,15)$. Pepsin and modified type II collagens were used to avoid variations in the immune response related to differences in the nonhelical terminal peptides, which are unimportant for development of arthritis. All preparations were stored lyophilized in a vacuum dessicator at $4^{\circ} \mathrm{C}$ until used.

The purity of each collagen preparation was assessed by amino acid analysis using an automatic analyzer (Beckman Instruments, Inc., Spinco Div., Palo Alto, Calif., model 121) and sodium dodecyl sulfate polyacrylamide electrophoresis as described $(16,17)$. In each case there was no detectable contamination by noncollagenous protein or by other types of collagen.

Immunization. Complete Freund's adjuvant (CFA) ${ }^{1}$ was prepared by pulverizing lyophilized heat-killed mycobacteria (strains C, DT, and PN, Ministry of Agriculture, Fisheries, and Food; Weybridge, Surrey, England) with a mortar and pestle. The ground mycobacteria were added to incomplete Fruend's adjuvant (Difco Laboratories, Detroit, Mich.) at a concentration of $2 \mathrm{mg} / \mathrm{ml}$. This suspension was sonicated (Sonifier Cell Disrupter model W185, Heat Systems-Ultrasonics, Inc., Plainview, N. Y.) at $50 \mathrm{~W}$ for $20 \mathrm{~s}$. Type II collagen was dissolved in $0.01 \mathrm{~N}$ acetic acid at a concentration of $2 \mathrm{mg} / \mathrm{ml}$ by stirring overnight at $4^{\circ} \mathrm{C}$. When denatured collagen was used, an aliquot of the solution of native collagen was placed in a boiling water bath for $5 \mathrm{~min}$ to obtain denatured collagen. Equal volumes of CFA and collagen solution were emulsified by sonication at $50 \mathrm{~W}$ for $10 \mathrm{~s}$, which was repeated after $2 \mathrm{~min}$. Temperature was maintained by the use of an ice bath. Each mouse received 0.1 $\mathrm{ml}$ of cold emulsion by injection intradermally in the tail. A booster injection of $100 \mu \mathrm{g}$ of type II collagen in $0.01 \mathrm{~N}$ acetic acid was given on day 21 intraperitoneally without adjuvant.

Arthritis evaluation. Mice were observed daily for the presence of arthritis. Data are presented for the presence of definite arthritis with both erythema and swelling without attempting to grade severity. In addition, swelling was quantitated by measuring the thickness of the foot and the width of the ankle with a constant tension caliper (Dyer Co., Inc., Lancaster, Pa.).

Mononuclear cell cultures. Cellular immunity was assessed by measuring antigen-induced $\left[{ }^{3} \mathrm{H}\right]$ thymidine incorporation. Spleen or lymph node cells were dissected free from surrounding connective tissue and gently teased apart in Hanks' balanced salt solution supplemented to contain 10 $\mathrm{mM}$ Hepes, pH 7.4. Clumps were removed by filtration through sterile gauze, and cells were harvested by centrifugation at $200 \mathrm{~g}$ for $6 \mathrm{~min}$. Erythrocytes were removed by resuspension of the cell pellet in $0.015 \mathrm{M}$ Tris/ $/ 0.14 \mathrm{M} \mathrm{NH}_{4} \mathrm{Cl}$, pH 7.4. After centrifugation cells were washed three times with Hanks' balanced salt solution and resuspended in an enriched tissue culture medium (TCM) ${ }^{1}$ as described by Click et al. (18), except modified to contain $20 \mathrm{mM}$ Hepes, pH 7.4. Cell concentration was adjusted to $2 \times 10^{6} / \mathrm{ml}$ and fresh normal autologous mouse serum was added to a final concentration of $2 \%$.

Cell cultures were performed in sterile round bottom microplates (Nunc, Div. Vanguard International, Neptune, N. J.) by aliquoting $100 \mu \mathrm{l}$ of cell suspension into each well. An additional $100 \mu \mathrm{l}$ of TCM containing the appropriate

${ }^{1}$ Abbreviations used in this paper: BUDR, bromodeoxyuridine; CFA, complete Fruend's adjuvant; TCM, enriched tissue culture medium; PBS, phosphate-buffered saline. concentration of antigen was added to each of quadruplicate wells. Plates were incubated at $37^{\circ} \mathrm{C}$ in $5 \% \mathrm{CO}_{2}$ and $95 \%$ air for $96 \mathrm{~h}$. During the final $4 \mathrm{~h}$ of culture each well was pulsed with $0.5 \mu \mathrm{Ci}$ of $\left[{ }^{3} \mathrm{H}\right]$ thymidine. Cells were harvested on glass fiber filters using a multisample microharvesting device (Flow Laboratories, Inc., Rockville, Md.) and washed extensively with water. Filters were dried and the incorporation of the label measured by liquid scintillation spectrometry. Results are expressed as $\Delta \mathrm{cpm}$ where $\Delta \mathrm{cpm}$ $=$ counts in antigen-stimulated culture - counts in culture with medium alone. Background incorporation varied from 0.8 to $1.8 \times 10^{3} \mathrm{cpm}$ and quadruplicate cultures varied by no more than $10 \%$.

Antigens used consisted of collagen and purified protein derivative of mycobacteria (PPD). Collagen for use in tissue culture was dissolved in $0.01 \mathrm{~N}$ acetic acid at a concentration of $2 \mathrm{mg} / \mathrm{ml}$ by stirring overnight at $4^{\circ} \mathrm{C}$ and sterilized by microporous filtration. This solution was either used directly or heated for $5 \mathrm{~min}$ on a boiling water bath when denatured collagen was needed. Because the tissue culture medium was highly buffered no appreciable change in $\mathrm{pH}$ occurred with addition of as much as $5 \%$ of $0.01 \mathrm{~N}$ acetic acid. For a control antigen PPD was dissolved in $0.04 \mathrm{M}$ phosphate/0.15 M $\mathrm{NaCl}, \mathrm{pH} \mathrm{7.4}$, at a concentration of $1 \mathrm{mg} / \mathrm{ml}$ and diluted with TCM so that a final concentration in culture of $5 \mu \mathrm{g} /$ ml resulted.

Treatment with bromodeoxyuridine (BUDR) and light. To determine if the cellular proliferation assay could detect conformational determinants on native type II collagen not present on denatured collagen, spleen cells were cultured with denatured collagen, the proliferating cells killed by treatment with BUDR followed by exposure to light, and the remaining cells restimulated with native collagen. The method used was a modification of that previously reported $(19,20)$. Spleen cells were obtained as described above but were cultured at a concentration of $10^{6}$ cells $/ \mathrm{ml}$ in $1 \mathrm{ml}$ of TCM with $2 \%$ fresh autologous serum in polystyrene tubes (Falcon 2054, Falcon Labware, Div. Becton Dickinson \& Co., Oxnard, Calif.). Antigens used included PPD at $5 \mu \mathrm{g} /$ $\mathrm{ml}$ concentration, native type II collagen $25 \mu \mathrm{g} / \mathrm{ml}$ and denatured type II collagen $25 \mu \mathrm{g} / \mathrm{ml}$. The initial culture period was $72 \mathrm{~h}$ with $5 \mu \mathrm{l}$ of $1 \mathrm{mM}$ BUDR added to each tube for an additional $18 \mathrm{~h}$ of culture. The cultures were then exposed to high intensity fluorescent light for $90 \mathrm{~min}$. BUDR-containing culture supernatant fluids were gently aspirated using a pasteur pipette and $1 \mathrm{ml}$ of fresh TCM containing $1 \%$ normal autologous serum and the appropriate antigen was added to each tube. The cells were gently resuspended and recultured for $96 \mathrm{~h}$ in humidified air with $5 \% \mathrm{CO}_{2}$ avoiding further exposure to light. Cultures were pulsed with $1 \mu \mathrm{Ci}$ of $\left[{ }^{3} \mathrm{H}\right]$ thymidine during the final $4 \mathrm{~h}$ of culture and were harvested on glass fiber filters. The filters were washed sequentially with $10 \mathrm{ml}$ cold phosphate-buffered saline (PBS), $10 \mathrm{ml}$ of cold $10 \%$ trichloroacetic acid, and absolute methanol. Dry filters were placed in vials, $5 \mathrm{ml}$ of scintillation fluid added and incorporation of the label measured by liquid scintillation spectrometry. Assays of triplicate samples were performed and individual cultures did not vary by $>20 \%$ from the mean of the replicates.

Immunoassay of antibodies to collagen. An enzymelinked immunoassay system (Gilford EIA 50, Gilford Instrument Laboratories Inc., Oberlin, Ohio) was used to detect antibodies to collagen. The methods used were adapted from those of Engvall and Perlmann (21). Disposable polystyrene cuvettes were coated with collagen as follows: collagen was dissolved in 0.4 ionic strength phosphate buffer, $\mathrm{pH} 7.6$ by stirring overnight at $4^{\circ} \mathrm{C}$. Collagen concentration was ad- 
justed to $25 \mu \mathrm{g} / \mathrm{ml}$ based on specific absorbance at $230 \mathrm{~nm}$ as detected by spectrophotometry. Aliquots of $250 \mu \mathrm{l}$ of collagen solution were placed in each cuvette. Cuvettes were incubated at $4^{\circ} \mathrm{C}$ overnight or until used.

Before use the collagen-coated cuvettes were washed at $4^{\circ} \mathrm{C}$ with PBS and incubated for $1 \mathrm{~h}$ with PBS containing $0.5 \%$ ovalbumin (grade V, Sigma Chemical Co., St. Louis, Mo.) to reduce nonspecific absorbance. Four additional washes were performed with PBS containing 0.05\% Tween 20 (PBS-Tween). Serum was diluted with PBS-Tween containing $0.5 \%$ ovalbumin and $250-\mu l$ aliquots of each dilution placed in duplicate or triplicate cuvettes. After incubation at $4^{\circ} \mathrm{C}$ overnight cuvettes were washed with PBS-Tween, an appropriate dilution of conjugate was added, and incubation continued for $4 \mathrm{~h}$. Excess conjugate was washed out using PBS-Tween and the amount of conjugate specifically bound determined by adding 5 amino-salicylic acid as a substrate. After incubation at room temperature for $1 \mathrm{~h}$ the reaction product was measured by absorbance at $450 \mathrm{~nm}$. All of the sera for a given experiment were assayed simultaneously.

Conjugates used in these experiments consisted of Staphylococcal protein A-peroxidase (Zymed Laboratories, Burlingame, Calif.) to detect IgG and $\mu$-chain specific Rabbit anti-mouse IgM-peroxidase (N. L. Cappel Laboratories Inc., Cochranville, $\mathrm{Pa}$.) to detect IgM. Dilutions of 1:1,000 and 1:500 were used respectively based on preliminary studies of serial dilutions under the actual assay conditions. Substrate was prepared by dissolving $80 \mathrm{mg}$ of 5 amino-salicylic acid in $100 \mathrm{ml}$ of warm $\mathrm{H}_{2} \mathrm{O}$. The $\mathrm{pH}$ was adjusted to 6.0 at room temperature immediately before use and $10 \mathrm{ml}$ of $0.05 \%$ $\mathrm{H}_{2} \mathrm{O}_{2}$ added.

Sera were obtained either by cardiac puncture or if serial samples were needed by retroorbital bleeding. For the latter procedure a $40-\mu l$ heparinized capillary tube was used, and the plasma was separated by centrifugation. No difference between binding by serum and heparinized plasma obtained in capillary tubes was noted. All sera were frozen at $-80^{\circ} \mathrm{C}$ within $2 \mathrm{~h}$ and thawed once immediately before use.

\section{RESULTS}

Onset and course of arthritis. 23 of 24 mice (96\%) immunized with native type II collagen developed arthritis between 4 and 5 wk after the primary immunization. Onset was sudden with maximal severity developing over 24-48 h (Fig. 1). The ankle joint was most often involved. Initially there was slight redness that quickly spread to involve the entire foot with marked redness and edema. Thickness of the dorsum of the foot increased from $1.41 \pm 0.12$ to $2.40 \pm 0.20 \mathrm{~mm}$ and intermalleolar thickness from $2.73 \pm 0.22$ to $4.84 \pm 0.40 \mathrm{~mm}$ (mean $\pm \mathrm{SE})$. The onset of forepaw involvement was most prominent in the wrist with swelling of the digits developing over the next 3-10 d. Forepaw involvement was less frequent than hind paw (Table I). In two mice there was isolated involvement of a single interphalangeal joint. There was no clinically evident involvement of the tail or spine. Histologic examination of arthritic joints 1 wk after onset showed synovial proliferation and infiltration with mononuclear cells (Fig. 2). Arthritis could not be in- duced by immunization with denatured collagen as the immunogen ( 0 of 10 mice immunized).

Collagen immunity in arthritic mice. When spleen cells from arthritic mice were cultured in the presence of native type II collagen, increased incorporation of $\left[{ }^{3} \mathrm{H}\right]$ thymidine occurred with increasing collagen concentrations up to $25 \mu \mathrm{g} / \mathrm{ml}$ (Fig. 3). No increase in $\left[{ }^{3} \mathrm{H}\right]$ thymidine incorporation was observed at native collagen concentrations in excess of $25 \mu \mathrm{g} / \mathrm{ml}$. Concentrations of native collagen in excess of $25 \mu \mathrm{g} / \mathrm{ml}$ also caused a marked variation in the response among quadruplicate cultures and between animals. This may have been due to the propensity for native collagen to form fibrils in neutral solution. The effect was not noted in cultures in which denatured collagen was used. Denatured collagen was also a more effective stimulator of proliferation on a milligram basis, but because denaturation results in three $\alpha$-chains from each native molecule, it was comparable on a molar basis.

Humoral immunity was measured using an ELISA system. Sera from immunized mice and nonimmunized controls were separately pooled. Various dilutions of these sera were incubated in enzyme-linked immunoassay (ELISA) cuvettes coated with native type II collagen. Both IgM and IgG showed a high degree of binding at low dilutions of immune sera (Fig. 4). Sera obtained 2 and $5 \mathrm{wk}$ after immunization were analyzed for IgM and IgG, respectively. Among individual sera there were detectable differences in binding by IgG of immune sera as compared with nonimmune sera at dilutions of $10^{-4}$ and occasionally in as high a dilution as $10^{-5}$. The levels of absorbance for IgM were uniformly lower but this might be related to the potency and specific activity of the conjugate. For both conjugates a slight rise in nonspecific background occurred at high serum dilutions that never exceeded $0.10 \mathrm{U}$ of absorbance.

Time-course of the immune response. The proliferative response of spleen cells from immunized mice to collagen was measured at various intervals after immunization (Fig. 5). All mice were immunized at day 0 and killed at intervals. Four immune mice and two nonimmune controls were included at each time point. Cultures were performed in the presence of $25 \mu \mathrm{g}$ of native collagen that was prepared as a single batch and stored in aliquots at $-80^{\circ} \mathrm{C}$ until used. Maximal $\left[{ }^{3} \mathrm{H}\right]$ thymidine incorporation in response to collagen was detected at 2 wk with a decline at 3 wk and a second rise at $4 \mathrm{wk}$, presumably due to the booster immunization. However, this second rise did not achieve the same level as was detected at $2 \mathrm{wk}$. None of the normal controls had any response to collagen. The response to PPD was included as a control antigen and this response also peaked at $2 \mathrm{wk}$ but then steadily 

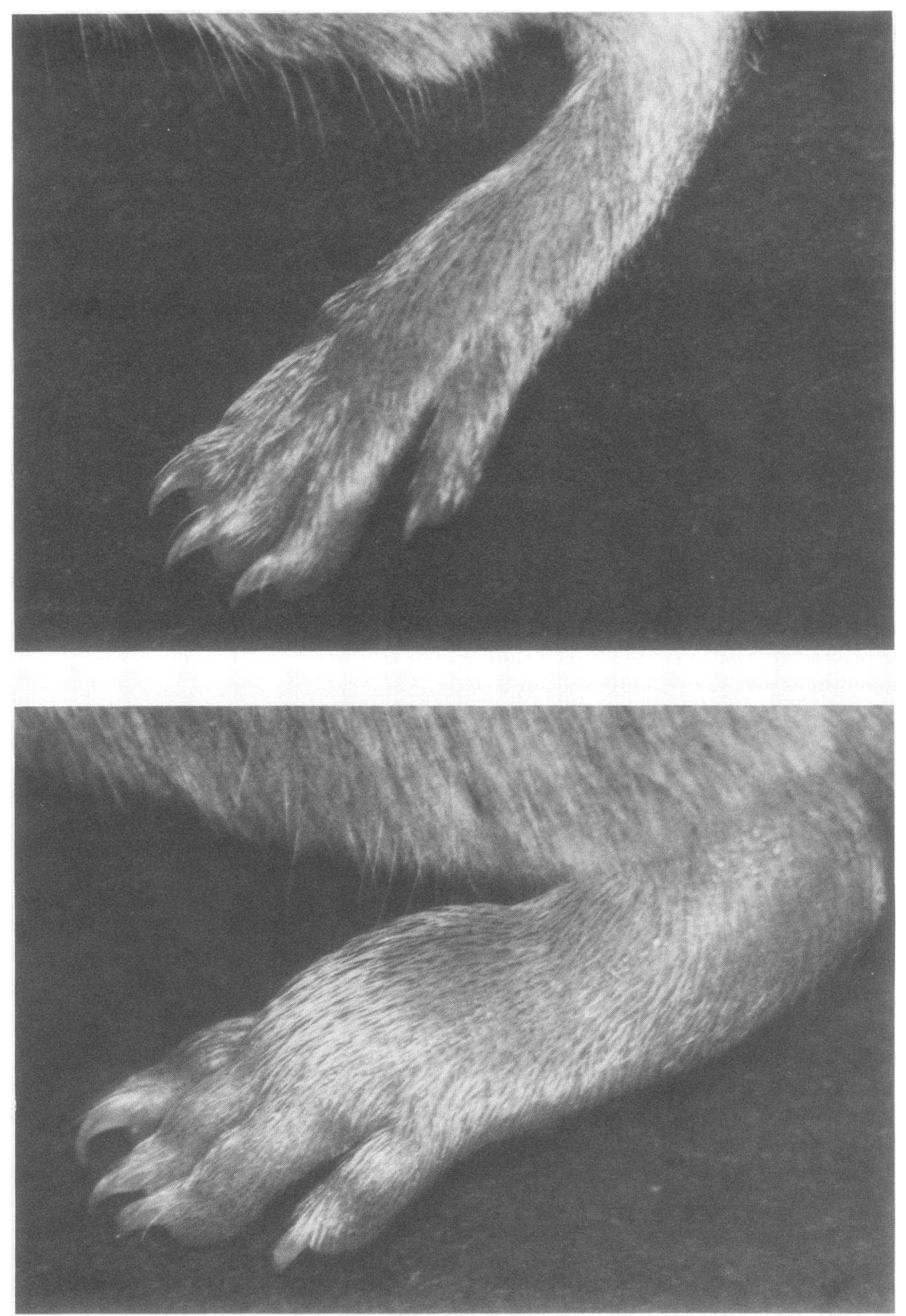

FIGURE 1 Comparison of a normal mouse hindpaw (above) with that of an arthritic mouse (below). The arthritic mouse was immunized with $100 \mu \mathrm{g}$ of chick type II collagen in CFA and received a booster injection of $100 \mu \mathrm{g}$ of collagen intraperitoneally without adjuvant at day 21 . Arthritis developed at day 30 and this photograph was taken $24 \mathrm{~h}$ later.

declined. At none of the timepoints tested did the response to collagen equal or exceed that to PPD. Furthermore, the collagen response declined to low levels by $6-8$ wk while the PPD response persisted.

Humoral immunity was assessed by measuring both IgM and IgG anticollagen antibody levels. The data shown (Fig. 6) represent the mean levels of 10 mice that were bled serially and analyzed simultaneously. A plasma dilution of 1:2,000 was used for detection of IgG and 1:100 for detection of IgM. The purpose of the experiment was to show the relative time-course of the IgM and IgG responses and not the absolute levels. IgM antibody levels were maximal at 2 wk after immunization. No increase in IgM was detected after 
TABLE I

Pattern of Clinically Evident Joint Involvement ${ }^{\circ}$

\begin{tabular}{cc}
\hline Involved joints & Number of mice \\
\hline 0 & $1(4 \%)$ \\
1 & $9(37.5 \%)$ \\
2 & $9(37.5 \%)$ \\
3 & $3(12.5 \%)$ \\
4 & $2(8 \%)$ \\
& $4(17 \%)$ \\
Only forepaw & $8(33 \%)$ \\
Only hindpaw & $11(46 \%)$ \\
Both fore- and hindpaw
\end{tabular}

- 24 mice were immunized with $100 \mu \mathrm{g}$ of type II collagen emulsified in CFA by intradermal injection in the tail. Each received a booster injection of $100 \mu \mathrm{g}$ of collagen intraperitoneally without adjuvant at $3 \mathrm{wk}$. The total period of observation was 8 wk.

the booster immunization. IgG antibody levels however were maximal at 4-5 wk. The onset of arthritis was also at 4-5 wk-a time when IgG anticollagen levels were maximal. Both cellular proliferation in response to collagen and IgM antibody levels were declining at the time arthritis became clinically evident.

Immunogenicity of native and denatured collagen. Because native type II collagen has been shown to be a more potent immunogen than the denatured molecule when administered in incomplete Freund's adjuvant in rats, and because denatured collagen will not induce arthritis in rats or mice, it was possible that the development of arthritis was related to the magnitude of the immune response rather than to specificity for native collagen. To test this hypothesis, 10 mice were immunized with either native or denatured collagen and studied at 2 and 5 wk after the primary immunization for cell-mediated and humoral immunity to type II collagen, respectively (Table II). It was apparent that denatured collagen when given with CFA was an effective immunogen in mice. Spleen cells from mice immunized with denatured collagen had as good a proliferative response to native and denatured type II collagen as did cells from mice immunized with native collagen. Antisera from mice immunized with denatured type II collagen had as high a titer as antisera from mice immunized with native type II collagen when each was tested against their respective immunogens. Under these experimental conditions there was no difference in the immunogenicity of native and denatured type II collagen. However, only the native collagen was effective in inducing arthritis. It was apparent that the arthritogenic property of type II collagen was not due to differences in immunogenicity but to the tertiary structure of the helical portion of the molecule.

Specificity of the immune response. It was of in- terest to determine whether either the cell-mediated or humoral immune response in arthritic mice was specific for native type II collagen. Mice immunized with native type II collagen were bled and their spleens removed. Splenic mononuclear cells were cultured in the presence of various collagen preparations and their response measured by $\left[{ }^{3} \mathrm{H}\right]$ thymidine incorporation (Table III). Equally good incorporation was detected in response to native chick type II collagen, denatured chick type II collagen, native bovine type II collagen, and native chick type I collagen. These data suggest the cell-mediated response is not specific for native collagen nor for the species or type of collagen.

To determine whether the cells responding to native collagen were from the same population as those responding to denatured collagen, an experiment was performed to negatively select cells proliferating in response to denatured collagen. Splenic mononuclear cells were first cultured with denatured collagen and these cells killed by the addition of BUDR to the culture followed by exposure to light. These cultures were then restimulated with native collagen and residual activity measured (Table IV). No residual activity was detected in response to native collagen after cells responding to denatured collagen were eliminated. This could not have been due to nonspecific killing of the cells because reculture with the independent antigen PPD resulted in cellular proliferation. Native collagen was capable of stimulating proliferation under these circumstances because cells cultured with PPD and restimulated with collagen also had proliferative activity.

The specificity of the humoral response in arthritic mice was measured by inhibition of immune serum in the ELISA system using cuvettes coated with native type II collagen. A serum dilution of 1:2,000 was used based on the antibody binding curve (Fig. 4). Various collagen preparations were added to aliquots of the immune serum at several concentrations and after preincubation for $\mathbf{3 0} \mathrm{min}$ each aliquot was assayed for binding of native chick type II collagen. In contrast to cell-mediated immunity, the humoral response was highly specific and dependent upon the conformation of the molecule (Fig. 7). Binding was inhibited by $<25 \%$ after preincubation with denatured type II collagen or native type I collagen at concentrations up to $100 \mu \mathrm{g} / \mathrm{ml}$. The same serum was substantially inhibited by $1 \mu \mathrm{g}$ and completely inhibited by $5 \mu \mathrm{g}$ of the native chick type II collagen used as immunogen. When bovine native type II collagen was used to inhibit binding, an intermediate degree of inhibition was noted. This indicated that in the mouse antisera obtained after immunization with native type II collagen were partially species specific, markedly type specific, and reacted with conformationally determined bind- 


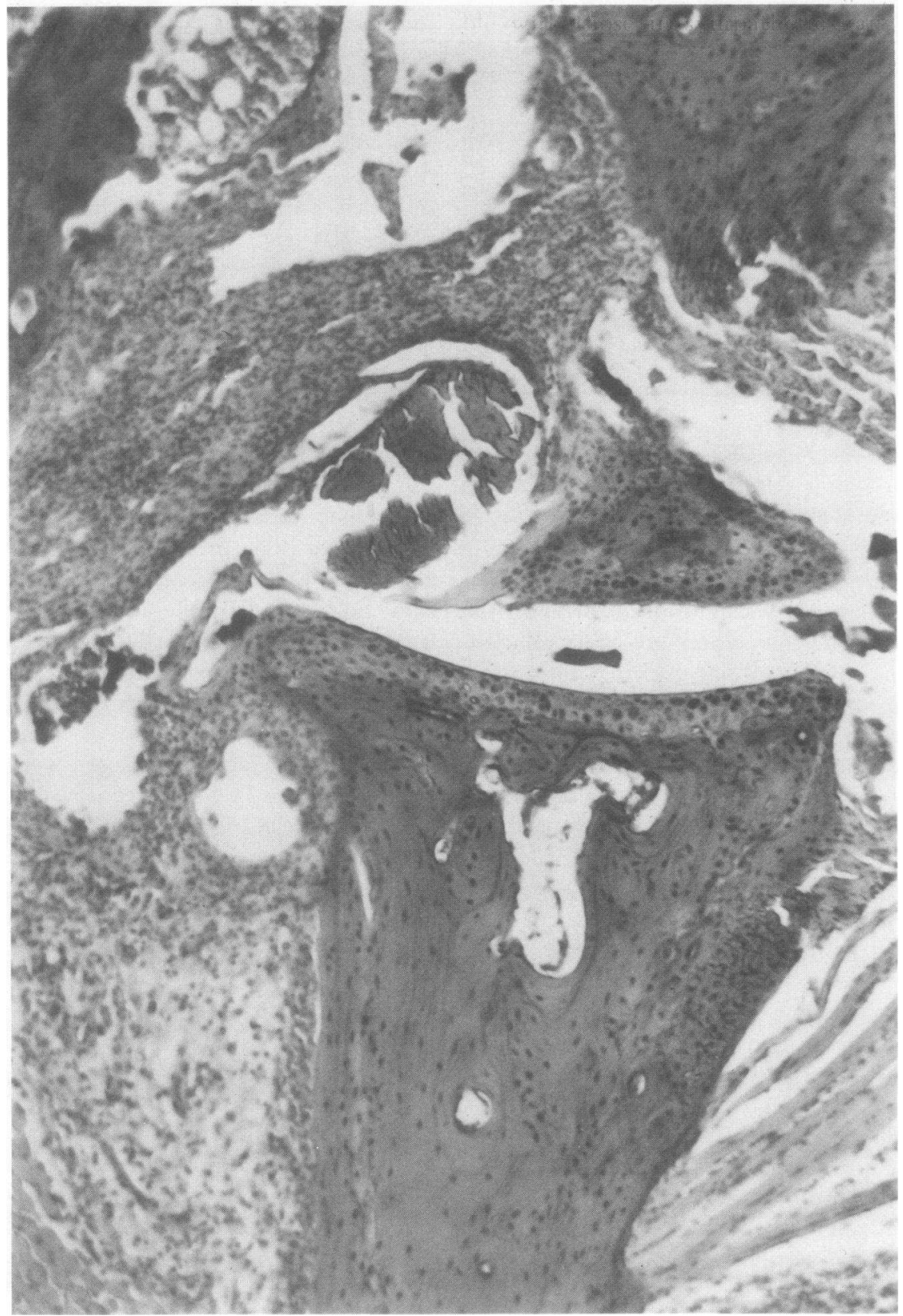

FIgURE 2 Histopathology of an ankle joint from a mouse $3 \mathrm{~d}$ after the onset of arthritis. Marked cellular infiltration of the synovium is present with distension of the joint capsule. The cartilage appears damaged but is largely intact. On higher power examination most of the cells appear to be mononuclear, but many neutrophils were also seen. A marginal erosion is beginning to develop. Hemtoxylin and eosin $\times 112$.

ing sites. However, antiserum obtained after immunization with denatured chick type II collagen was substantially inhibited by both denatured and native chick type II collagen and by denatured bovine type II collagen (Fig. 8). While this antiserum reacted with native collagen, it appeared to be primarily specific for covalent structural determinants and may have bound to a different epitope.

\section{DISCUSSION}

These data indicate that DBA/1 mice immunized with native chick type II collagen will develop an inflam- 


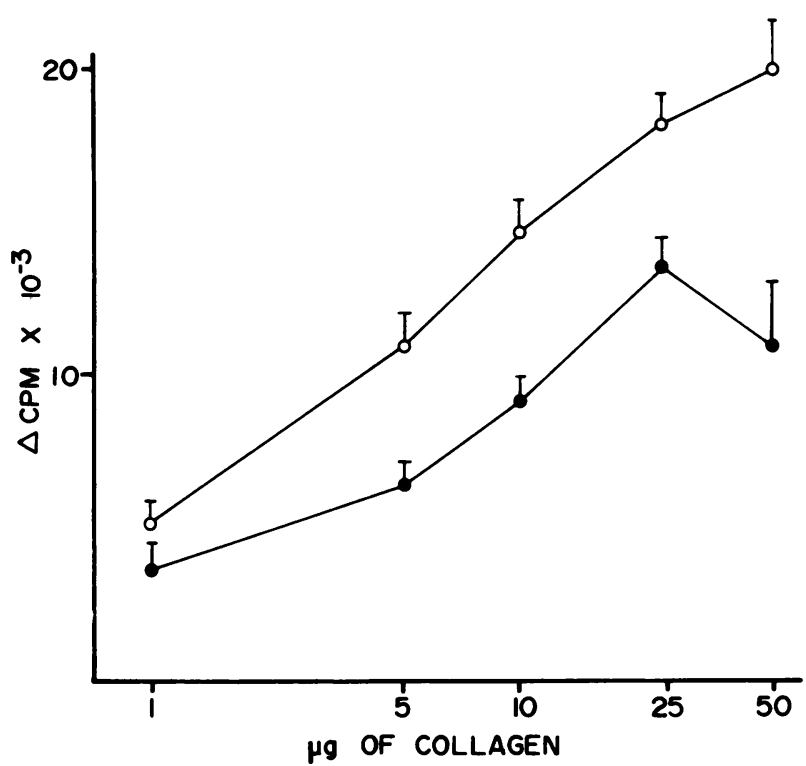

Figure 3 Proliferative response to native ( $)$ and denatured collagen (O). Spleen cells were obtained 2 wk after immunization with $100 \mu \mathrm{g}$ of native type II collagen in CFA, cultured in the presence of each antigen for $96 \mathrm{~h}$, and incorporation of $\left[{ }^{3} \mathrm{H}\right]$ thymidine measured. The vertical bar with crosshatch represents the standard error of the mean for four cultures.

matory polyarthritis. The histopathology of the arthritis is similar to that seen in collagen-induced arthritis in rats and both resemble that seen in human rheumatoid arthritis. There are, however, a number of differences in the immune response observed in mice as compared with that in rats. In rats the arthritis

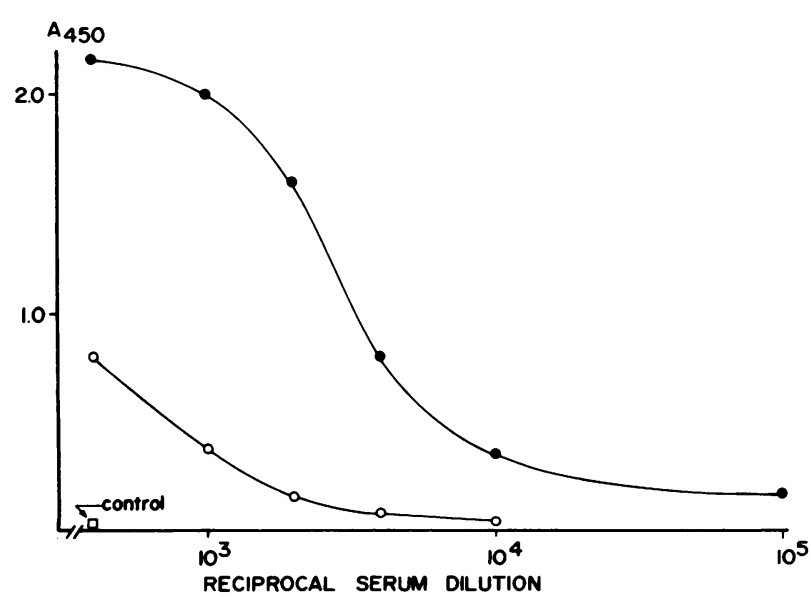

Figure 4 Binding of native type II collagen by immune mouse serum in the ELISA assay. IgG (๑) levels were detected using peroxidase-protein $A$ and pooled sera from mice obtained 5 wk after primary immunization. IgM (O) levels were detected using peroxidase-anti IgM ( $\mu$-chain specific) and pooled sera from four mice obtained 2 wk after immunization.

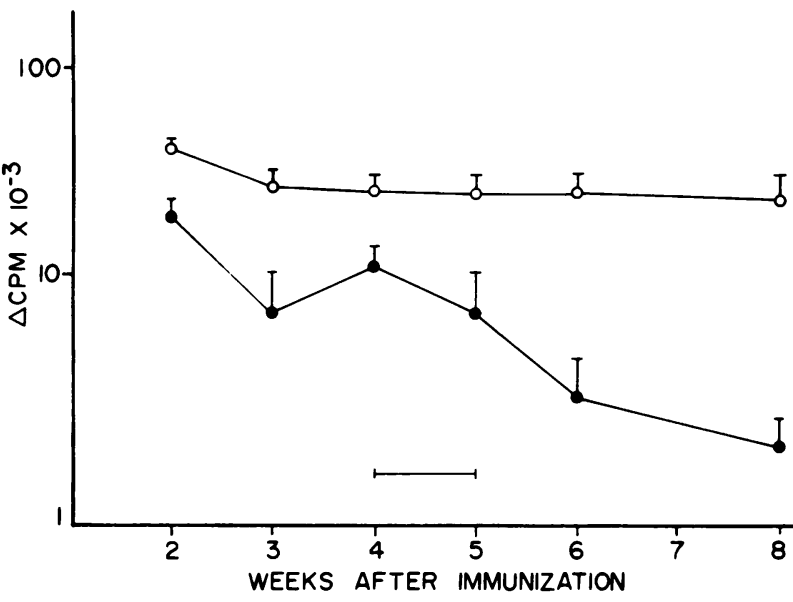

Figure 5 Proliferative response to native type II collagen (O) and PPD (O). Spleen cells were cultured with each of these antigens for $96 \mathrm{~h}$ and $\left[{ }^{3} \mathrm{H}\right]$ thymidine incorporation measured. The vertical bar and crosshatch represent the SEM for four mice. Horizontal bar shows the time period during which arthritis developed. Nonimmune mice were included as controls at each timepoint but none of these responded to collagen.

developed after a latent interval of 2 wk when both cell-mediated immunity and antibody levels to collagen were rising (3). Mice developed disease 4-5 wk after primary immunization when cell-mediated immunity and IgM antibody levels were declining but when IgG antibody levels were rising. Furthermore, in rats both the cell-mediated response, measured by

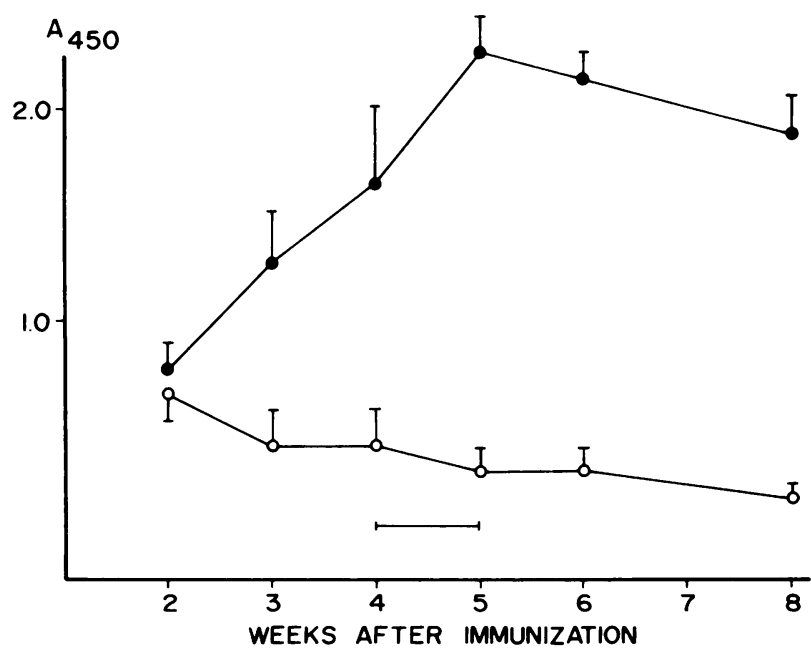

Figure 6 Time-course of the antibody response to native type II collagen. IgG (O) (serum dilution $1: 1,000)$ and IgM (O) (serum dilution 1:50) were measured by ELISA using peroxidase-protein $A$ and peroxidase-anti IgM ( $\mu$-chain specific), respectively. The vertical bars with crosshatch represent the SEM for 10 mice studied serially. The horizontal bar shows the time period during which arthritis developed. 
TABLE II

Cellular and Humoral Response of Mice Immunized with either Native or Denatured Chick Type II Collagen

\begin{tabular}{lllllc}
\hline \multirow{2}{*}{ Immunogen } & \multicolumn{2}{c}{${ }^{3}$ H Thymidine incorporation } & & \multicolumn{2}{c}{ Antibody titert } \\
\cline { 2 - 3 } \cline { 5 - 6 } & NII $(25 \mu \mathrm{g})$ & DII $(10 \mu \mathrm{g})$ & & NII & DII \\
\hline Native type II & \multicolumn{2}{c}{$\Delta c p m \times 10^{-3 \bullet}$} & & \\
Denatured type II & $11.9 \pm 0.5$ & $13.6 \pm 2.0$ & & $5 \times 10^{-4}$ & $5 \times 10^{-3}$ \\
\hline
\end{tabular}

- $2 \times 10^{5}$ spleen cells obtained 2 wk after primary immunization were cultured for 96 $h$ in the presence of native or denatured collagen. Data shown are the mean $\pm S E$ for quadruplicate cultures.

I Sera obtained 5 wk after primary immunization were assayed by ELISA in serial dilutions. The endpoint was defined as the highest dilution giving twice the absorbance as the same dilution of serum from an unimmunized control.

lymphocyte proliferation, and the antibody response were specific for native type II collagen (2). In contrast, the lymphocyte proliferative response in the mouse was not specific for native type II collagen. Type I collagen and denatured type II collagen would both evoke comparable proliferative responses when cultured with cells from mice immunized with native type II collagen. Furthermore elimination of cells reactive with denatured collagen by treatment with BUDR and light also abrogated the response to native collagen. This finding could not have been an artifact due to denaturation of the collagen as a result of the immunization procedure because the antibodies detected in the same mice were specific for conformational determinants and immunization with denatured collagen results in the production of antibodies of different specificity.

Our studies extend observations of the cellular immune response to collagen made by other investigators. Rosenwasser et al. (22) found that lymphocytes from

TABLE III

Nonspecificity of the Cellular Response of Mice Immunized with Native Type II Collagen

\begin{tabular}{lc}
\hline \multicolumn{1}{c}{ Stimulator } & ${ }^{3}$ HTThymidine incorporation \\
\hline & $\Delta c p m \times 10^{-3}$ \\
Native chick II, $25 \mu \mathrm{g} / \mathrm{ml}$ & $11.9 \pm 0.5$ \\
Denatured chick II, $10 \mu \mathrm{g} / \mathrm{ml}$ & $13.6 \pm 2.2$ \\
Native bovine II, $25 \mu \mathrm{g} / \mathrm{ml}$ & $13.3 \pm 2.5$ \\
Native chick I, $25 \mu \mathrm{g} / \mathrm{ml}$ & $13.3 \pm 2.4$ \\
Denatured chick I, $10 \mu \mathrm{g} / \mathrm{ml}$ & $11.6 \pm 1.6$ \\
\hline
\end{tabular}

- $2 \times 10^{5}$ spleen cells obtained 2 wk after immunization with native chick type II collagen were cultured in the presence of each collagen preparation for $96 \mathrm{~h}$. Values given are the mean \pm SEM for quadruplicate cultures. mice immunized with denatured collagen also reacted with several synthetic collagen-like polypeptides and postulated that $\mathrm{T}$ cell recognition may be dependent on amino acid sequence and not conformation. They did not examine the response after immunization with native collagen, however. Other investigators immunized guinea pigs with native type II collagen and showed they had equally good skin test reactivity to both native and denatured collagen (23). Our studies support the concept that immunization of mice with native type II collagen elicits cells reactive with both native and denatured collagen and that these cells are derived from the same population.

TABLE IV

Inability of Native Chick Type II Collagen to Stimulate Cellular Proliferation after Elimination of Cells Reactive with Denatured Collagen ${ }^{\circ}$

\begin{tabular}{llr}
\hline \multirow{2}{*}{ Initial stimulant } & \multicolumn{1}{c}{$\begin{array}{c}\text { Secondary } \\
\text { stimulant }\end{array}$} & $\times 10^{-3} \pm$ SEM \\
\hline & & \\
& & \\
Denatured CII & None & $2.5 \pm 0.4$ \\
& PPD & $30.6 \pm 4.2$ \\
& Native CII & $2.6 \pm 0.6$ \\
PPD & Denatured CII & $3.4 \pm 1.0$ \\
& None & $6.7 \pm 1.0$ \\
& PPD & $9.1 \pm 1.6$ \\
& Native CII & $20.5 \pm 3.0$ \\
& Denatured CII & $28.4 \pm 3.4$ \\
\hline
\end{tabular}

- Cells were cultured for $72 \mathrm{~h}$ in the presence of the initial stimulant. BUDR was included during the last $18 \mathrm{~h}$ of culture and the cultures exposed to high intensity fluorescent light to kill proliferating cells. Triplicate cultures were restimulated with the antigens indicated and harvested $96 \mathrm{~h}$ later. Data shown is from a representative mouse immunized with native type II collagen and studied 2 wk later. 


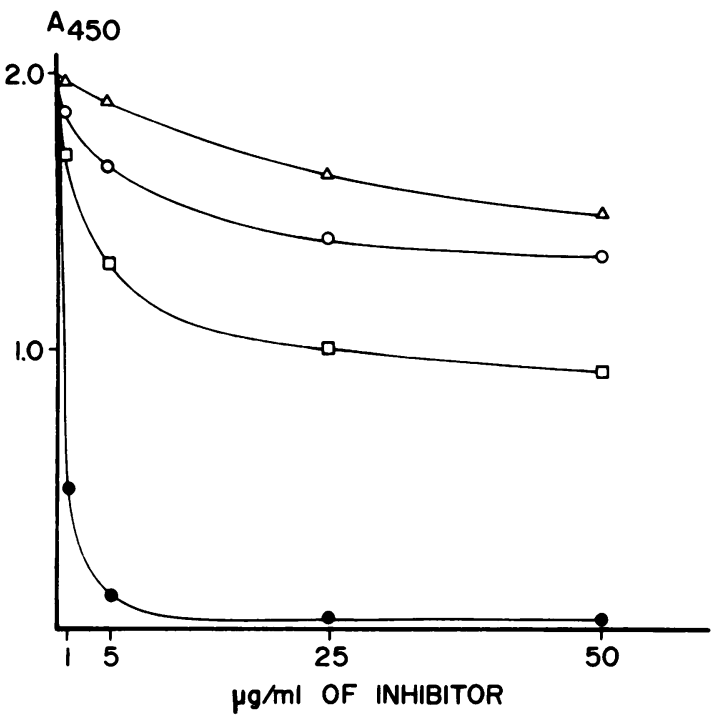

Figure 7 Inhibition studies performed using sera from arthritic mice. ELISA cuvettes were coated with native chick type II collagen. Pooled sera from four arthritic mice obtained $5 \mathrm{wk}$ after immunization was diluted 1:2,000 and aliquots were preincubated for $30 \mathrm{~min}$ with each inhibitor: -native chick type II, O-denatured chick type II, 口native bovine type II, $\Delta$-native chick type I. Binding of each aliquot + inhibitor was detected using peroxidase-protein A.

On the other hand, we found the antibody reaction in mice immunized with native collagen was highly specific for the helical conformation of native collagen, a finding similar to that reported in rats by Hahn et al. (24). The latter investigators also reported that the antibody responses of mice to bovine types I and II collagen were under genetic control and that the responses could be separated from one another because the $\mathrm{H}-2^{\mathrm{b}}$ and $\mathrm{H}-2^{\mathrm{s}}$ haplotypes were high responders to type I collagen, whereas $\mathrm{H}-2^{\mathrm{q}}$ and $\mathrm{H}-2^{\mathrm{s}}$ were high responders to type II (25). They were unable to investigate the immunogenicity of denatured collagen due to the high binding of denatured collagen by normal sera in their assay system. Our studies suggest that although immunization with denatured collagen results in an antibody level comparable to that seen after immunization with native collagen, the antibody specificity is different. We have previously shown the arthritic response in mice is also genetically linked and that arthritis is associated with high antibody titers to type II collagen (26). However, some strains with high antibody titers did not develop arthritis including those with the B10.S and B10.D2 haplotypes.

Both rats and mice require immunization with native type II collagen in order to develop arthritis. Other types of collagen and denatured type II collagen are not effective in inducing arthritis. In the rat immu- nization with other types of collagen evoked lower levels of both cell-mediated and humoral immunity to the respective immunogens $(2,27)$. Under the conditions used for immunization in the mouse, however, denatured type II collagen was capable of inducing both cell-mediated and humoral responses of comparable magnitudes to those seen when native type II collagen was the immunogen. In fact, the lymphocyte proliferative response was indistinguishable from that obtained with native collagen. The data suggest, however, that the antibodies obtained after immunization with denatured collagen were primarily directed against covalent structural determinants and while they cross-reacted with native collagen, they may have bound to a different epitope. Although detailed studies have not been performed, strains of mice that produce high antibody titers in response to native type II collagen but do not develop arthritis may in fact have antibody of different specificity than that of the arthritic DBA/1 mice reported here (26). Arthritis may depend upon achieving a critical level of an antibody specific for a particular conformational determinant on native type II collagen. Other explanations for this finding are also possible and further investigation will be necessary to clarify this point.

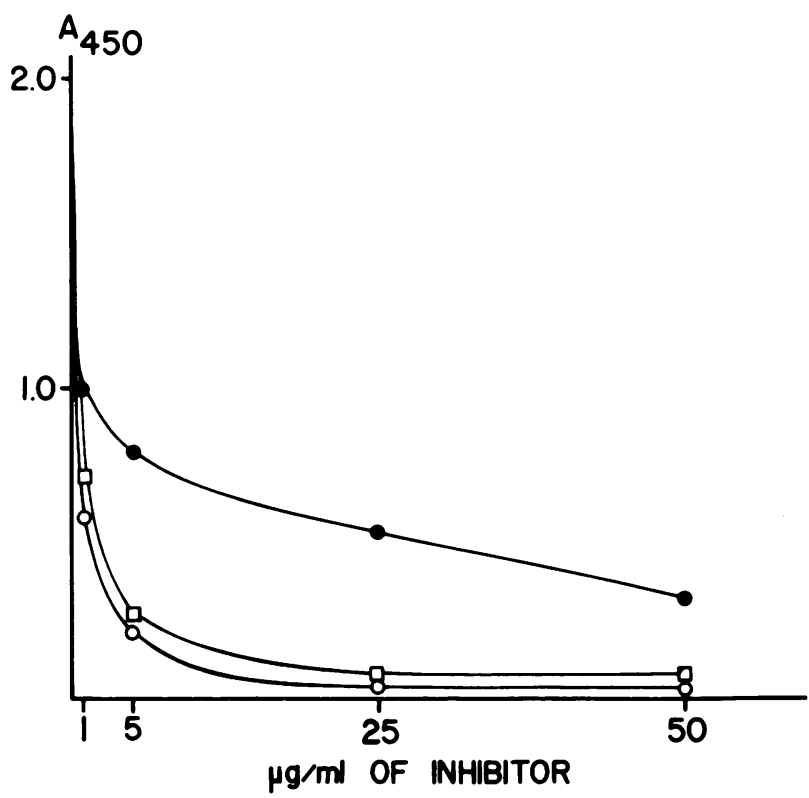

Figure 8 Inhibition studies performed using sera from mice immunized with denatured collagen. ELISA cuvettes were coated with denatured chick type II collagen. Aliquots of pooled sera from four mice obtained $5 \mathrm{wk}$ after immunization with denatured chick type II collagen were preincubated for $30 \mathrm{~min}$ with each inhibitor: -native chick type II, O-denatured chick type I, $\square-$ denatured bovine type II. Binding of each aliquot inhibitor was detected using peroxidase-protein $A$. 
Recent studies of collagen-induced arthritis in the rat also support the hypothesis that the antibody response is important in the induction of arthritis. We have previously shown that when collagen-induced arthritis in the rat was modified by pretreatment with various immune modulating drugs, arthritis was temporally associated with high levels of antibodies to type II collagen (28). Clague et al. (29) reported a correlation between antibody levels and arthritis in different strains of rats. We and others have found that arthritis is never seen in the absence of high levels of anti-type II collagen antibodies [unpublished observation, (28)]. And finally we have been able to transfer arthritis in rats using a cell-free serum extract that contained anti-type II collagen antibodies (30).

These studies may have implications for human arthritis. The histopathology of the arthritis in both rats and mice resembles that seen in rheumatoid arthritis. Rheumatoid arthritis has also been associated with a major histocompatibility complex gene namely HLADRw4 (31). Finally, collagen autoimmunity has also been described in rheumatoid arthritis and it has been postulated that collagen autoimmunity may initiate or perpetuate the disease $(5,7)$. However, because collagen autoimmunity has also been described in relapsing polychondritis (9), systemic sclerosis (10), and other rheumatic diseases $(8,11)$, which are clinically distinct entities, it is likely that this finding represents (a) a secondary reaction that is inconsequential, (b) part of a final common pathway through which joint destruction occurs as a result of diverse initiating factors, or $(c)$ the nature and specificity of the reaction is different in different diseases. Our present studies would suggest that the finding of antibodies specific for native type II collagen would be most consistent with the mouse and rat animal models. It has been reported that antibodies of that specificity are present in some patients with rheumatoid arthritis $(32,33)$. This finding needs to be confirmed and additional studies of the specificity of the immune reactions seen in other rheumatic diseases made and compared with those seen in rheumatoid arthritis.

Our studies do not define the role of cell-mediated immunity in collagen-induced arthritis in rodents. It has been reported that disease in rats can be transferred with cells from either arthritic or nonarthritic immunized donors (4). Neither cell-mediated immunity nor antibodies to collagen were detected in recipients, however, and the significance of these experiments is not yet clear. It is evident that immunity to native type II collagen is intimately associated with the development of an inflammatory polyarthritis in both rats and mice and although the present findings suggest the critical importance of antibodies with particular specificity for native type II collagen, addi- tional studies are needed to define the exact pathogenetic mechanisms involved. Only by identifying those mechanisms can meaningful comparisons be made to human arthritic diseases.

\section{ACKNOWLEDGMENTS}

The authors thank Mrs. Marcia Anderson for her excellent technical assistance.

This work was supported by funds from the Veterans Administration and by National Institutes of Health grant AM00650.

\section{REFERENCES}

1. Trentham, D. E., A. S. Townes, and A. H. Kang. 1977. Autoimmunity to type II collagen: an experimental model of arthritis. J. Exp. Med. 146: 857-868.

2. Trentham, D. E., A. S. Townes, and A. H. Kang. 1978. Humoral and cellular sensitivity to collagen in type II collagen-induced arthritis in rats. J. Clin. Invest. 61: 8996.

3. Stuart, J. M., M. A. Cremer, A. S. Townes, and A. H. Kang. 1979. Collagen-induced arthritis in rats: evaluation of early evaluation of early immunologic events. Arthritis Rheum. 12: 1344-1351.

4. Trentham, D. E., R. A. Dynesius, and J. R. David. 1978. Passive transfer by cells of type II collagen-induced arthritis in rats. J. Clin. Invest. 62: 359-366.

5. Steffen, C., and R. Timpl. 1963. Antigenicity of collagen and its application in the serological investigation of rheumatoid arthritis sera. Int. Arch. Allergy Appl. Immunol. 22: 333-349.

6. Andriopoulos, N. A., J. Mestecky, G. J. Miller, and E. L. Bradley. 1976. Antibodies to native and denatured collagens in sera of patients with rheumatoid arthritis. Arthritis Rheum. 19: 613-617.

7. Trentham, D. E., R. A. Dynesius, R. E. Rocklin, and J. R. David. 1978. Cellular sensitivity to collagen in rheumatoid arthritis. N. Engl. J. Med. 299: 327-332.

8. Stuart, J. M., A. E. Postlethwaite, A. S. Townes, and A. H. Kang. 1980. Cell-mediated immunity to collagen and collagen of chains in rheumatoid arthritis and other rheumatic diseases. Am. J. Med. 69: 13-18.

9. Foidart, J. M., A. Shigeto, G. R. Martin, T. M. Zizic, E. V. Barnett, T. J. Lawley, and S. I. Katz. 1978. Antibodies to type II collagen in relapsing polychrondritis. N. Engl. J. Med. 299: 1203-1207.

10. Stuart, J. M., A. E. Postlethwaite, and A. H. Kang. 1976. Evidence for cell-mediated immunity to collagen in progressive systemic sclerosis. J. Lab. Clin. Med. 88: 601607.

11. Huffstutter, J. E., J. M. Stuart, A. S. Townes, and A. H. Kang. 1980. Antibodies to native and denatured collagens in rheumatic diseases utilizing radioimmunoassay Clin. Res. 28: 147S. (Abstr.).

12. Courtenay, J. S., M. J. Dallman, A. D. Dayan, A. Martin, and $B$. Mosedale. 1980. Immunization against heterologous type II collagen induces arthritis in mice. Nature (Lond.). 283: 666-668.

13. Cremer, M. A., J. M. Stuart, A. S. Townes, and A. H. Kang. 1980. Collagen-induced polyarthritis in rats: a study of native type II collagen for adjuvant activity. $J$. Immunol. 124: 2912-2918.

14. Trelstad, R. L., A. H. Kang, B. P. Tooler, and J. Gross. 1972. Collagen heterogeneity: high resolution separation 
of native $[\alpha 1(\mathrm{I})]_{2} \alpha 2$ and $[\alpha \mathrm{l}(\mathrm{II})]_{3}$ and their component $\alpha$ chains. J. Biol. Chem. 247: 6469-6473.

15. Stuart, J. M., M. A. Cremer, S. N. Dixit, A. S. Townes, and A. H. Kang. 1979. Collagen-induced arthritis in rats: comparison of vitreous and cartilage-derived collagens. Arthritis Rheum. 22: 347-352.

16. Seyer, J. M., E. T. Hutcheson, and A. H. Kang. 1976. Collagen polymorphism in idiopathic chronic pulmonary fibrosis. J. Clin. Invest. 57: 1498-1507.

17. Smith, G. N., T. F. Linsenmayer, and D. A. Newsome. 1976. Synthesis of type II collagen in vitro by embryonic chick neural retina tissue. Proc. Natl. Acad. Sci. U. S. A. 73: 4420-4423.

18. Click, R. E., L. Benck, and B. J. Alter. 1972. Immune responses in vitro. 1. Culture conditions for antibody synthesis. Cell Immunol. 3: 264-276.

19. Zoschke, D. C., and F. H. Bach. 1970. Specificity of antigen recognition by human lymphocytes in vitro. Science (Wash., D. C.). 170:1404-1406.

20. Zoschke, D. C., and F. H. Bach. 1971. In vitro elimination of specific immunoreactive cells with 5-Bromodeosyuridine. J. Immunol. Methods. 1: 55-65.

21. Envall, E., and P. Perlmann. 1972. Enzyme-linked immunosorbent assay, III. Quantitation of specific antibodies of enzyme labeled anti-immunoglobulin in antigen coated tubes. J. Immunol. 109: 129-135.

22. Rosenwasser, L. J., R. S. Bhatnagar, and J. D. Stobo. 1980. Genetic control of the murine T-lymphocyte proliferative response to collagen: analysis of the molecular and cellular contributions to immunogenicity. J. Immunol. 124: 2854-2859.

23. Beard, K. H., M. Ueda, W. P. Faulk, and L. E. Glynn. 1978. Cell-mediated and humoral immunity to chick type II collagen and its cyanogen bromide peptides in guinea pigs. Immunology. 34: 323-335.

24. Hahn, E., R. Timpl, and G. J. Miller. 1974. The production of specific antibodies to native collagens with the chain compositions, $(\alpha \mathrm{l}(\mathrm{I}))_{3},(\alpha \mathrm{l}(\mathrm{II}))_{3}$ and $(\alpha \mathrm{l}(\mathrm{I}))_{2} \alpha 2$ J. Immunol. 113: 421-423.

25. Nowack, H., E. Hahn, and R. Timpl. 1975. Specificity of the antibody response in inbred mice to bovine type I and II collagen. Immunology. 29: 621-628.

26. Wooley, P. H., H. S. Luthra, J. M. Stuart, and C. S. David. 1981. Type II collagen-induced arthritis in mice. I. MHC (I region) linkage and antibody correlates. $J$. Exp. Med. 154: 688-700.

27. Morgan, K., R. B. Clague, M. J. Shaw, and P. J. L. Holt. 1980. Native type III collagen-induced arthritis in the rat. I. Incidence and humoral response to collagen. Ann. Rheum. Dis. 39: 285-290.

28. Stuart, J. M., L. K. Myers, A. S. Townes, and A. H. Kang. 1981. The effect of levamisole, hydrocortisone and cyclophosphamide on collagen-induced arthritis in rats. Arthritis Rheum. 24: 790-794.

29. Clague, R. B., K. Morgan, M. J. Shaw, and P. J. L. Holt. 1980. Native type II collagen-induced arthritis in the rat. 2. Relationship between the humoral immune response to native type II collagen and arthritis. J. Rheumatol. 7: 775-782.

30. Stuart, J. M., M. A. Cremer, A. S. Townes, and A. H. Kang. 1982. Collagen-induced arthritis in rats: passive transfer with serum and evidence that IgG can cause arthritis. J. Exp. Med. In press.

31. Stastny, P., and C. W. Fink. 1979. Different HLA-D associations in adult and juvenile rheumatoid arthritis. J. Clin. Invest. 63: 124-130.

32. Andriopoulos, N. A., J. Mestecky, G. P. Wright, and E. J. Miller. 1976. Characterization of antibodies to the native human collagens and to their component $\alpha$ chains in the sera and the joint fluids of patients with rheumatoid arthritis. Immunochemistry. 13: 709-712.

33. Beard, H. K., R. Ryvar, J. Skingle, and C. L. Greenbury. 1980. Anticollagen antibodies in sera from rheumatoid arthritis patients. J. Clin. Pathol. (Lond.). 33: 10771081 . 